\section{The Early Bird Gets the Word}

\author{
Merja Meriläinen ${ }^{a,{ }^{*}}$, Maarika Piispanen $^{\mathrm{b}}$
}

\begin{tabular}{ll}
\hline Received: & 29 March 2019 \\
Revised: $\quad 11$ June 2019 \\
Accepted: $\quad$ 09 August 2019 \\
ISSN: 1307-9298 \\
Copyright (C) IEJEE \\
www.iejee.com
\end{tabular}

DOI: 10.26822/iejee.2019155332

\begin{abstract}
Success in an increasingly globalized world sets requirements for versatile communication skills and understanding about other cultures. One of the keys to success is versatile language skills, on which the European Commission spoke out as early as in 1995, recommending that every European citizen should learn two foreign languages in addition to their mother tongue. Now, more than twenty years later, the launch of early foreign language teaching that is to begin in the first grade in Finland, in January 2020, is a significant step towards this goal. Studies show that early foreign language learning needs to be carefully carried out in order to achieve positive effects and the effects that have been set for it in the national language program and curriculum. The age when language teaching is started is, however, just one of many variables that are seen to be relevant to the development of foreign language skills in the framework of early foreign language teaching and learning. As early foreign language teaching is a very recent area of teaching in Finland, the policy - makers and teachers play a significant role in creating new kind of learning environments, operating culture and pedagogy for foreign language learning. This article discusses early foreign language learning landscape in the context of early foreign language learning theory, initial education pedagogy as well as functional foreign language learning. The cornerstone of this study is the Contextual Pedagogical approach to Learning, which creates a bridge between the theory and practice of early foreign language learning, creating an inspiring and stimulating basis for later language learning.
\end{abstract}

Keywords: Early Foreign Language Learning, Functional Language Learning, Learning Environments, Contextual-Pedagogical Approach to Learning

\section{Introduction}

In the current national core curriculum for basic education (Finnish National Board of Education, 2014) in Finland the emphasis on language education is greater than in earlier curricula (Finnish National Board of Education, 2004). Along with the language education in school, both home and leisure environments are equally seen as seedbeds for the multilingual competence of the pupils. The aim in teaching is to create bridges, not only between different languages, but also in the language usage of the pupils during leisure time. Language usage in different situations is seen as the basis for language teaching - known as functional language teaching, where language is primarily seen as a tool for communication (Finnish National Board of Education, 2014). What the learner is able to do with the language is essential to functionality; what kinds of language use situations, tasks and texts they can solve, both by understanding the language and by creating language (Nissilä, Martin, Vaarala, \& Kuukla, 2016, p.29). Functional approach to teaching a language emphasizes the learner's needs for language, language use situations that are meaningful for them as well as functioning within them.

Early foreign language teaching also relies on a functional view of language, to which Salmela (2011) in their study connects the concept of communicative language teaching. In communicative language teaching the teaching methods are based on utilizing communicative activities (Linna, 2018). Exercises that direct the pupils to talk and converse with each other, for example by telling each other about things that are important to them or by asking for advice or guidance are used as teaching methods and actions that guide the learning. Role-playing and different games are also used as methods in communicative language teaching. The guiding principle in planning the activity is the goal of having the pupils interact and communicate in a foreign language.

According to Nissilä et al. (2016) communicative studies and studies that emphasize the social nature of languages have steered the examination of language learning and absorption especially from the point of view that a language is not learned in order to communicate, but that it is learned precisely while communicating. Littlewood (1981) also emphasizes the significance of hearing exercises in interaction and views them as an important part of activities that are active and understanding. According to Littlewood the purpose of communicative activities is to create a context that supports learning that makes natural learning possible and improves the motivation of the learners by making the learning of a language meaningful for each individual learner. For this reason Littlewood sees the comprehensiveness of the exercises particularly important.

Authenticity is mentioned in the Finnish national core curriculum (POPS, 2014, p.243-246) in connection to teaching a foreign language; however, the curriculum does not define what is meant by authenticity more accurately. According to researchers (Gilmore, 2011; Rossi, 2013) the concept of authenticity is often unclear to the teacher of foreign languages, and the perceptions of authenticity vary.

Authentic early foreign language context should, according to Meriläinen and Piispanen (2013), be examined by considering if the language learning landscape with learning tasks, environments and contexts reflect those frameworks in which language is actually used. Will we be able to create such tasks and procedures that model the language use needs of real life? The way in which a pupil can become aware of the benefits accrued from their learning is also significant. Herrington, Reeves and Oliver (2010) note that the

\footnotetext{
a,*Corresponding Author: Merja Meriläinen, Kokkola University Consortium Chydenius Talonpojankatu 2b, 67100 Kokkola, Finland.

E-mail:merja.merilainen@chydenius.fi

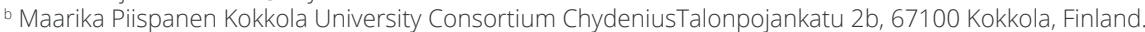

E-mail: maarika.piispanen@chydenius.fi
} 
learning environment has a great significance for learning: an authentic learning environment offers content and context that express ways in which the knowledge will be used in reality. Authentic context is created if learning becomes personally significant for the learner (Rule, 2006). Thus the authenticity in teaching and learning a foreign language is not only connected to the learning materials, but it needs to be understood more broadly and more comprehensively as a part of the operating culture, contexts and pedagogy.

As early foreign language learning is restricted to one weekly hour, or multiple shorter moments amounting to an hour, it is important according to Celaya (2012) to operate in the foreign language in as natural situation as possible. Personal experience and active participation as well as the possibility to actively influence the learning process offer the learners the experiences of succeeding. According to researchers (Linna, 2018; Tragant, 2006; Celaya, 2012) early foreign language learning has positive effects on children's attitudes and motivation, and according to Celaya (2012) motivation is the central factor in why early foreign language learning is beneficial, as motivation according to them is one of the key factors in learning a foreign language.

\section{Functional and Playfulness}

The functionality and the playfulness of the teaching methods has been emphasized time and time again in connection to the early foreign language learning that is launching in Finland, teachers have also been encouraged to develop and try out different working methods. Within the framework of learning and teaching the common denominator between the functional teaching methods and functional learning is that the pupil is an active agent and learning happens alongside the action. Together with functionality, the concepts of playfulness and play are commonly associated with the learning environments of early language learning. In the playful learning environments the pupils also take part in actions that take them towards the competence being pursued. It is stated in the national core curriculum for basic education.

Finnish National Board of Education (2014) that there is plenty of room for joy, playfulness and creativity in learning languages, and it gives directions to use versatile and functional methods.

According to Villaroel (2015) active, functional learning enables the children to fully take part in the learning process. In order to achieve this, learning environments that persuade pupils to learn comprehensively and by using all of the senses, must be utilized. Kangas (2014, p.84-85) also notes that playful learning environments also meet the need to bring the whole body into learning. Suitable learning activities include for example: songs, moving about, different games, videos, art and making things with one's own hands. Playful learning environments are often also communal, which makes learning social and thereby it has a natural communicative aspect. Kangas (2014) reminds, however, that playing itself does not give school learning more value. Playful learning environments must primarily be created from the point of view of pedagogics, when it is possible to reach the goals of competence placed on formal teaching.

\section{Language Skills of the Teachers}

The planning of early language landscapes puts various expectations and demands on the teachers. The task is demanding, for they need to have the knowledge and the know-how of both how a language is best learned in the framework of early language learning and how small children learn in general. The teacher's own language skill is also important, because the most important channel for learning a language for young language learners is, according to Cameron (2001), spoken language. In early foreign language teaching the pupils are in touch with the foreign language mainly through hearing the language. Mezzi (2012) emphasizes the importance of the speaking of the teacher in early foreign language teaching and instructs teachers to mainly speak the foreign language while teaching it. Keaveney and Lundberg (2014) also emphasize the importance of using the foreign language in early foreign language teaching; as, in connection to using their mother tongue the students are not as actively trying to understand the foreign language spoken by the teacher.

Theoretical Background: Building Bridges from Theory to Practice

The theoretical framework of early foreign language teaching, national core curriculum for basic education and small child pedagogics, as well as the teacher's role as the planner and realizer of the language landscape together are expected to create a successful framework for early foreign language teaching. Meriläinen and Piispanen (2018) have created a theoretical model to support the planning and realizing of the early foreign language learning landscape based on a theory of language learning. This model is the Contextual Pedagogical approach to early language learning landscape model, in which a strong seedbed for language skills and its development is created, especially in the early language learning environments.

\section{Contextual Pedagogy}

At the background of the Contextual Pedagogical approach to early language learning landscape model there is a functional view of language, which stems from the framework of authentic learning in which language is seen as a tool for communication and interaction as well as learning.

The learning process built with the help of this model makes the capturing of a foreign language deeper in functional and authentic learning environments, where there is room for communication and interaction, and where the contexts and pedagogics enable the child to learn through natural learning methods (Figure 1.)

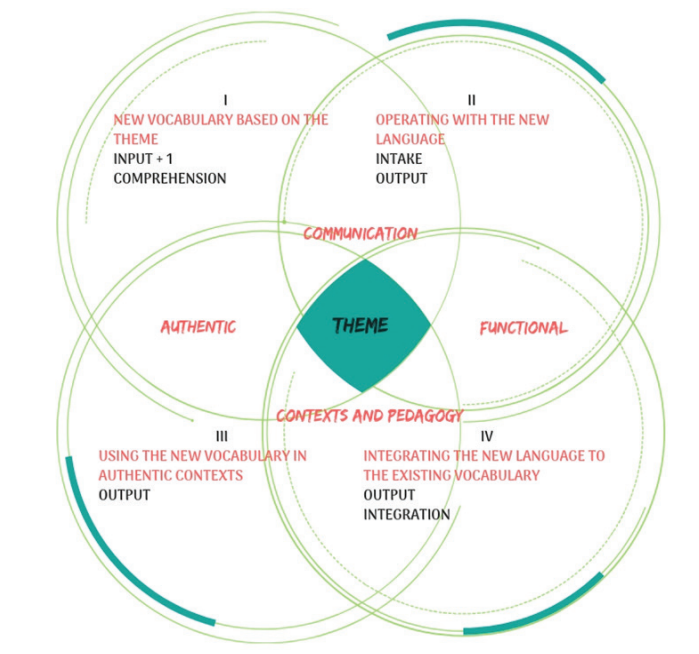

Figure 1. The Model of Contextual Pedagogical Early Foreign Language Learning Process (Merilainen \& Piispanen, 2018.)

The learning process in early language learning that has been planned within the Contextual-pedagogical language learning landscape proceeds through four stages 
that support language learning. During these consecutive stages the vocabulary, language skills and the level of language skills in the subject, which is motivating for the student, will grow and develop systematically and according to the goals that have been set for the teaching. The awareness of the type and level of language competence that is aimed for with the teaching guides the planning of the learning situations connected to the learning process and the choice of teaching methods that enable a versatile development of language skills. What is essential in the model is that the language is handled in natural situations that support the inherent actions of the child and that teaching the language is connected to the ongoing theme that arises from the multidisciplinary module through vocabulary and actions that is suitable for the context.

\section{Four Stages of The Contextual Pedagogical Approach}

The Contextual-pedagogical language learning process advances through four stages that support and develop language learning as follows:

- I the input of new language material (input + 1, comprehension)

- II internalizing the language material and producing speech (intake + output)

- III language as a part of contexts (output)

- IV deepening recollection and increasing vocabulary (output, integration)

In order for the child to become familiar with the vocabulary, phrases, language landscape and the actions within it, sufficient time is spent in the four stage learning process of the theme that has been chosen for teaching. Thus, the teacher will also have enough time to observe the development of the pupils' language skills in the different areas of language competence, especially in understanding and producing speech. The pupils on the other hand have experiences of success, as the games, play and stories as well as the foreign language material connected to them become familiar to them as they work with one theme. According to Targant (2006) it is essential to maintain the internal positive attitude of the child towards the language that is being learned. She feels it is important that the pupils have plenty of experiences of success, as it can be difficult for the child to notice their progress during just one hour a week of early foreign language learning, which in turn weakens their motivation and impacts their attitudes.

Stage I: The Input of New Language material (Input + 1, Comprehension)

The first stage of the early foreign language learning process planned in the Contextual -pedagogical language learning landscape starts with the input of new language material (input +1 ), when the theme reliant language material that has been chosen for teaching exceeds the level of language competence of the pupils at the time, however, their understanding (comprehension) of it is supported with pictures, gestures and expressions in a way that it becomes suitably understandable for the pupils, as well as interesting and exciting. According to Krashen (1985), input means the language material produced in the process of learning a foreign language that the learner of a new language observes. In Finnsif early language learning contexts, the +1 indicates that the language material is more challenging for the pupils and that they are aiming to understand this material in the learning process. Input hypothesis is based on Krashens $(1982,1985)$ language acquisition and learning theory, where he claims that people learn foreign language by understanding message or by receiving comprehensible input. According to Krashen, speaking is a result of acquisition of a new language. If input is understood, and there is enough of it, the necessary grammar is automatically provided. In the Contextual -pedagogical language learning landscape the input of the new language material is achieved through actions that are natural for children, with the help of stories, songs and play in a way that the central vocabulary and phrases, as well as the language that is heard and spoken are strongly present and become familiar to the child. (Meriläinen \& Piispanen, 2018.)

The description phrases of the different levels of language competence of The Common European Framework of Reference for Languages guide the planning of the learning process and how it advances. With the help of these phrases the planned actions move towards the goals that have been set for them from the point of view of early foreign language and development of language skills. In the table below (Table 1) is presented a learning situation that has been planned for the first stage of learning in the Contextual-Pedagogical early foreign language learning landscape and learning functions that aim towards the goal, with the help of the Christmas themed learning process planned for early foreign language learning: Santa is Coming Soon!

Table 1. Input of new language material (input +1 )

\begin{tabular}{|c|c|c|c|}
\hline Theme & $\begin{array}{c}\text { Key } \\
\text { vocabulary }\end{array}$ & $\begin{array}{l}\text { Phrases to learn- } \\
\text { ing aims (pre-A1) }\end{array}$ & $\begin{array}{c}\text { Input }+1 \text { and } \\
\text { comprehension } \\
\text {-learning tasks }\end{array}$ \\
\hline $\begin{array}{l}\text { Christ- } \\
\text { mas } \\
\text { Santa is } \\
\text { Coming } \\
\text { soon! }\end{array}$ & $\begin{array}{l}\text { Christmas, } \\
\text { Santa, } \\
\text { Rudolf, sleigh, } \\
\text { pie, jacket, } \\
\text { hat, present, } \\
\text { snowball, } \\
\text { toys, tree, } \\
\text { chimney, } \\
\text { colors } \\
\text { and numbers }\end{array}$ & $\begin{array}{l}\text { I can understand } \\
\text { simple, short } \\
\text { instructions given } \\
\text { by } \\
\text { my teacher. } \\
\\
\text { I can deduce the } \\
\text { meaning of a } \\
\text { word } \\
\text { from an accompa- } \\
\text { nying } \\
\text { picture or icon. }\end{array}$ & $\begin{array}{l}\text { Christmas -story- } \\
\text { time: Santa and } \\
\text { Rudolf are } \\
\text { getting ready } \\
\text { for Christmas } \\
\text { Tell me a story } \\
\text {-game } \\
\text { We wish you a } \\
\text { Merry Christmas } \\
\text {-song }\end{array}$ \\
\hline
\end{tabular}

The central vocabulary of the theme arises from Christmas time related words, that are from a subject matter that is familiar to children, with which they will spend at least a month on early language learning lessons, or if the teacher so wants in smaller sessions more often during a week for a month. The skill level descriptions of the framework that directed the planning of the learning process will become concrete in the process as learning tasks and situations, in which reaching the goal is possible for everyone and can be easily observed.

In the example above, the input of new language material (input +1 ) begins with a story time. The teacher is holding the picture cards for the story Santa and Rudolf are getting ready for Christmas, with the help of which they tell the story to the pupils. As the language and its vocabulary are to a large part foreign to the children it is important that the teacher supports understanding with dramatic effects: tone, gestures, facial expressions and repetition. As Krashen (1982;1985) highlights, the language used in the beginning of the storytime, the input of a new language, is the one which is only slightly above the current level of the learner's competence. This input is made comprehensible because of the help provided by the context.

The children are allowed to comment freely in Finnish and the teacher utilizes this interaction by communicating in a natural way in English. After the story telling, the story is repeated together with the help of the picture cards. During the retelling of the story, central words are repeated, and pronunciation is practiced by repeating and tasting 
the words. As most of the exposure to the language in early foreign language teaching happens through hearing the language, it is important that the teacher uses the language diversely and throws themselves bravely and creatively into supporting understanding with their whole body, tone and by putting their soul into the story. (See Mezzi, 2012; Jaekel, 2017).

Inputting new language material continues with playing in connection to the already familiar story. In the game "Tell me a story", the picture cards from the story have been attached all over the classroom. Although learning to read and write is not essential in early foreign language teaching, the written forms of foreign words may help the pupils to see the letters written in a different way or letters that are silent. According to Mezzi (2012) it is also beneficial for the development of vocabulary for the children to see written forms, as the recollection will be stronger when several senses are used.

As the learning session progresses, the teacher tells the story again freely and eloquently in their own words. The task of the pupils is to go to the accompanying relevant picture, directed by the story. When the correct picture has been found, they repeat the word, which the teacher connects in various different ways to full sentences, for example like this:

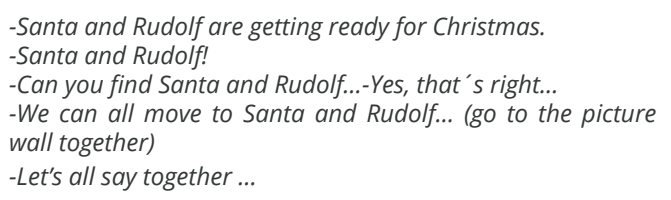

The goal that has been set for the development of language skills rises from the pre-A1 descriptions of the language skill levels of Communicative Language Activities and Strategies section: I can understand simple, short instructions given by my teacher. I can deduce the meaning of a word from an accompanying picture or icon.

To end the learning session the teacher and pupils sing and play We wish you a Merry Christmas together. When the song is familiar, an action is added to it, for example Let's do some clapping, etc. The children can also suggest actions and the teacher gives English lyrics to the ideas. The most important task of the teacher, according to Mezzi (2012) is to make the children produce words themselves.

Stage II: Internalizing the Language Material and Producing Speech (Intake + Output)

In the second stage of the Contextual-pedagogical early foreign language learning process the understanding and capturing of the language material (vocabulary and phrases) introduced in the first stage, as well as speaking and communicating in a foreign language (intake + output) are deepened.

According to Reinders $(2012$, p.28) intake is a subset of the detected input, comprehended or not, held in short-term memory, from which connections with long-term memory are potentially created or strengthened. Intake is not created solely by exposure to input; input needs processing for intake, and intake is a stage between input and acquisition. Output in turn has its roots in Swains (1985) Output Hypothesis, where she proposes that it is through language production that foreing language aquisition may be more likely to occur. According to Swain, it is during language production stages that young learners realise what they already know and and able to speak. This may happen when a learner is trying to convey a message but his or her linguistic knowledge of the second language is insufficient to do so. It is then that the learner realises that he ignores some useful words needed to express a desired message. For early foreign language learners' output is mainly oral use of the foreign language.

Practicing pronunciation is naturally connected to this stage. The new vocabulary is fortified, taking into consideration the pupils' own interests. The learning tasks are connected to contexts that are natural to the children. In the second stage of the learning process the pupils are offered plenty of functional and interactive actions, as well as activities that direct towards communication that help the pupils to process the new language material and speak it in natural authentic language use situations (output).

In the Table 2 is presented a learning situation that has been planned for the second stage of learning in the Contextual-pedagogical early foreign language learning landscape and learning functions that aim towards the goal, with the help of the Christmas themed learning process planned for early foreign language learning: Santa is Coming Soon!

Table 2. Internalizing and taking into use a new language operative stage (intake and output)

\begin{tabular}{|c|c|c|c|}
\hline Theme & $\begin{array}{c}\text { Key } \\
\text { vocabulary }\end{array}$ & $\begin{array}{l}\text { Phrases to learn- } \\
\text { ing aims (pre-A1) }\end{array}$ & $\begin{array}{l}\text { Input }+1 \text { and } \\
\text { comprehension } \\
\text {-learning tasks }\end{array}$ \\
\hline \multirow{4}{*}{$\begin{array}{l}\text { Christ- } \\
\text { mas } \\
\text { Santa is } \\
\text { Coming } \\
\text { soon! }\end{array}$} & \multirow{4}{*}{$\begin{array}{c}\text { Christmas, } \\
\text { Santa, } \\
\text { Rudolf, sleigh, } \\
\text { pie, jacket, } \\
\text { hat, present, } \\
\text { snowball, } \\
\text { toys, tree, } \\
\text { chimney, } \\
\text { colors } \\
\text { and numbers }\end{array}$} & $\begin{array}{l}\text { I can understand } \\
\text { simple, short } \\
\text { instructions given } \\
\text { by my teacher. }\end{array}$ & $\begin{array}{l}\text { I can understand } \\
\text { simple, short } \\
\text { instructions given } \\
\text { by my teacher. }\end{array}$ \\
\hline & & $\begin{array}{l}\text { I can make } \\
\text { simple purchases } \\
\text { through pointing } \\
\text { to objects or using } \\
\text { gestures. }\end{array}$ & $\begin{array}{l}\text { I can make } \\
\text { simple purchases } \\
\text { through pointing } \\
\text { to objects or using } \\
\text { gestures. }\end{array}$ \\
\hline & & $\begin{array}{l}\text { I can deduce } \\
\text { the meaning of } \\
\text { a word from an } \\
\text { accompanying } \\
\text { picture or icon. }\end{array}$ & $\begin{array}{l}\text { I can deduce } \\
\text { the meaning of } \\
\text { a word from an } \\
\text { accompanying } \\
\text { picture or icon. }\end{array}$ \\
\hline & & $\begin{array}{c}\text { I can recognize } \\
\text { numbers. }\end{array}$ & $\begin{array}{c}\text { I can recognize } \\
\text { numbers. }\end{array}$ \\
\hline
\end{tabular}

The second stage of the learning process begins with the songs, stories and games that are familiar from the previous lesson. The teacher can, if they so wish, choose from the previous lesson the most suitable games for the skills and enthusiasm of the children and remain with these familiar actions and the foreign language connected to them for a little longer. Meriläinen (2008) emphasizes that once moving on to a new theme the vocabulary of the theme should be heard as much as possible, so that the children have the correct vocabulary at their disposal with which to function and do different tasks.

Internalizing and taking the new language into use, as well as functioning with the language (intake and output) are realized with the game A Big Surprise, where the children get to play in small groups while being living pieces of the game. They count the numbers from the dice out loud and move accordingly. There are also surprises in the game, where you do different actions according to the clue words in the game squares. The Hop-card moves the pieces to the familiar Santa and Rudolf are getting ready for Christmas picture cards and the aim is to arrange the pictures into the correct order. The story is told together by revising the familiar words and speaking out loud. The Read-card takes the players around to a deck of cards that has been prepared out of the pictures of the story and together the embers of the group will play and read the pictures out loud and arrange them in the correct order of the story. The story is revised together and telling the 
story is practiced with the guidance from the teacher in the foreign language. Underneath The Play-card square is a memory game with illustrations from the familiar story.

The most sought after square of the game is A Big Surprise card -square, which takes the players directly to the finish. After reaching the finish the players go to a Christmas market to get a Christmas card with a little coloring picture on it. At the Christmas market they meet an English speaking salesperson (a teacher or a guest), who will help the children do their shopping: "Can I have a Santa -card, please! Etc. The children can also just say the word on the card they want "Santa, please." or "One Santa card, please." or point at the card they want on the poster. The salesperson guides the actions with natural language choices, repeats what the children say in English and enlivens the action with diverse gestures and facial expressions. At the end of the game all the other children reaching the finish line also go to the Christmas market and to complete the game everybody colors their cards.

The goal set for the development of language skills rises from the pre-A1 descriptions of the language skill levels of Communicative Language Activities and Strategies section: I can understand simple, short instructions given by my teacher. I can deduce the meaning of a word from an accompanying picture or icon. I can recognize numbers. I can make simple purchases through pointing to objects or using gestures.

\section{Stage III: Language as a Part of Contexts (Output)}

In the third stage of the early foreign language learning process the vocabulary and language of the theme are connected as parts of authentic context, where the learning situations and actions enable a child to use the language to communicate in natural settings. Learning new words becomes more diverse, however, when the words are linked to natural contexts and they are practiced in natural, authentic, speaking situations.

In the Table 3 is presented a learning situation that has been planned for the third stage of learning in the Contextual-pedagogical early foreign language learning landscape and learning functions that aim towards the goal, with the help of the Christmas themed learning process planned for early foreign language learning: Santa is Coming Soon.

Table 3. Language as a part of contexts (output)

\begin{tabular}{|c|c|c|c|}
\hline Theme & $\begin{array}{c}\text { Key } \\
\text { vocabulary }\end{array}$ & $\begin{array}{l}\text { Phrases to learn- } \\
\text { ing aims (pre-A1) }\end{array}$ & $\begin{array}{l}\text { Input }+1 \text { and } \\
\text { comprehension } \\
\text {-learning tasks }\end{array}$ \\
\hline $\begin{array}{l}\text { Christ- } \\
\text { mas } \\
\text { Santa is } \\
\text { Coming } \\
\text { soon! }\end{array}$ & $\begin{array}{c}\text { Christmas, } \\
\text { Santa, } \\
\text { Rudolf, sleigh, } \\
\text { pie, jacket, } \\
\text { hat, present, } \\
\text { snowball, } \\
\text { toys, tree, } \\
\text { chimney, } \\
\text { colors } \\
\text { and numbers }\end{array}$ & $\begin{array}{l}\text { I can understand } \\
\text { simple, short } \\
\text { instructions given } \\
\text { by my teacher. } \\
\\
\text { I can interact with } \\
\text { people if they } \\
\text { speak slowly and } \\
\text { repeat the words I } \\
\text { don't understand } \\
\text { and then help me } \\
\text { plan what I am } \\
\text { trying to say. } \\
\\
\text { I can recognize } \\
\text { numbers. }\end{array}$ & $\begin{array}{c}\text { Christmas -land } \\
\text {-game } \\
\text { Find a match - } \\
\text { game } \\
\text { The legend of the } \\
\text { Christmas tree } \\
\text {-story } \\
\text { Up On The House- } \\
\text { top -song }\end{array}$ \\
\hline
\end{tabular}

In the third stage of the Santa is Coming Soon! learning process even deeper memories are created and the language reserve is broadened by connecting vocabulary and play actions to authentic language use situations. Words and expressions that have been learned are put to use in authentic game contexts in both Christmas land and Find a match games. The session starts again with games that are familiar to the children, with which the growing language skills are strengthened further. In the game Christmas land the children play a board game, where they try to get to the finish line on the exact number on the die. The players throw the die and count their progress out loud repeating the numbers and trying to avoid the Rest squares on the board, where travelling slows down collectively. The player in the Rest square throws the die and chooses the number of cards from the Play card -deck given by the die. The group of players together goes through what is happening in the picture cards and recollect the story Santa and Rudolf are getting ready for Christmas. The players revise the story together by recollecting and telling what happens in each picture of the story, for example like this:

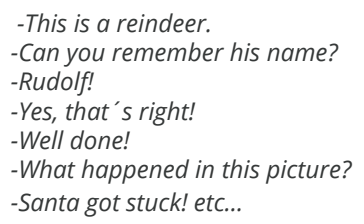

The winner of the game gets to choose the next activity, which can be either a story: The legend of the Christmas tree, or a Super Simple song video: Up On The House Top. This activity concludes the session.

The goal set for the development of language skills rises from the pre-A1 descriptions of the language skill levels of Communicative Language Activities and Strategies section: I can understand simple, short instructions given by my teacher. I can interact with people if they speak slowly and repeat the words I don't understand and then help me plan what I am trying to say. I can recognize numbers.

Stage IV: Deepening Recollection and Increasing Vocabulary (Output, Integration)

In the fourth stage of the Contextual-pedagogical early foreign language learning process the vocabulary of the chosen theme has become familiar to the children through games, playing, songs and stories.

In the fourth stage of the language learning process the words, sayings and phrases that have been learned will be practiced in new language use situations, where the goal is to deepen the recollection (integration) and broaden the use of the learned language material and transferring it into speech (output). In the last stage of the process the language material and the speaking situations connected to it are familiar to the children. It is easy for both the teacher and the children to observe the growth and broadening of the language skills during the learning process, which in part increases the motivation to learn new things. It becomes possible for the new language material to become a part of the early language learner's language reserves, when the learning process of early foreign language learning advances according to the plan that enables the growing of the language skills and has a goal.

In the Table 4 is presented a learning situation that has been planned for the fourth stage of learning in the Contextual-pedagogical early foreign language learning landscape and learning functions that aim towards the goal, with the help of the Christmas themed learning process planned for early foreign language learning: Santa is Coming Soon! 
Table 4. Language as a part of contexts (output)

\begin{tabular}{cccc}
\hline Theme & $\begin{array}{c}\text { Key } \\
\text { vocabulary }\end{array}$ & $\begin{array}{c}\text { Phrases to learn- } \\
\text { ing aims (pre-A1) }\end{array}$ & $\begin{array}{c}\text { Input +1 and } \\
\text { comprehension } \\
\text {-learning tasks }\end{array}$ \\
\hline $\begin{array}{c}\text { Christmas, } \\
\text { Santa, } \\
\text { Christ- } \\
\text { mas } \\
\text { Santa is } \\
\text { pie, jacket, } \\
\text { Coming } \\
\text { soon! } \\
\text { hat, present, } \\
\text { snowball, } \\
\text { toys, tree, } \\
\text { chimney, } \\
\text { colors } \\
\text { and numbers }\end{array}$ & $\begin{array}{c}\text { I can understand } \\
\text { instructions given } \\
\text { by my teacher }\end{array}$ & $\begin{array}{c}\text { Colors -salad } \\
\text { I can understand } \\
\text { the words for } \\
\text { christmas }\end{array}$ & $\begin{array}{c}\text { colors. } \\
\text { presents mystery } \\
\text {-game }\end{array}$ \\
\hline
\end{tabular}

In the fourth stage of the learning process the processing of the language material of the theme continues and the words that have been learned are taken into use in new situations, through new games. In the game Colors -salad, Santa has mixed up the presents and the cards and the children must help Santa find the correct card for each present. In this game the familiar cards from the story Santa and Rudolf are getting ready for Christmas have been color coded. In the beginning of the game the colors are revised together and it is ascertained that everyone remembers and recognizes the color as they hear them later. The teacher or one of the children shows the others one of the cards they are looking for and says:

-Who has a green reindeer card? Everyone with a green reindeer card shouts:

-I have a green reindeer card! At the same time the card holders change places with each other.

The game can be made more challenging by bundling a green reindeer card and a pink doll card together, etc. This means the children need to concentrate more on listening.

In Christmas presents mystery game children work with colors and the central vocabulary coming from the story Santa and Rudolf are getting ready for Christmas.

The small presents in Santa's sack are color coded with the colors of the cards and the children try to find a pair for the cards and presents, like this for example:

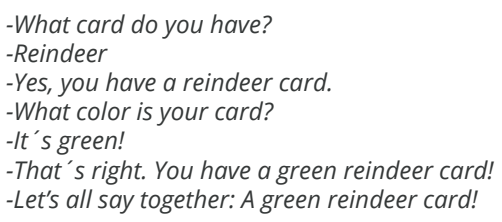

-Now, close your eyes. -Let's see if you can find a green Christmas present from Santa's sack! -Well done! / Oh dear!

With their eyes closed the children search for the same color present from Santa's sack as the card they have in their hands. With each card a conversation like the one illustrated above is had and it is expanded on and deepened as the child's language skills develop.

The goal set for the development of language skills rises from the pre-A1 descriptions of the language skill levels of Communicative Language Activities and Strategies section as follows: I can understand simple, short instructions given by my teacher. I can understand the words for colors.

The games, play, songs and stories of the Santa is Coming soon! -theme can be used every day in December and they can also be visited in small sessions at a time. It is significant for learning a foreign language that the language landscape is present in the child's everyday life as often as possible. According to Graham (2017) fifteen minutes a day is more efficient for learning a new language than one learning session a week.

\section{Discussion and Conclusion}

As in most European countries, first foreign language is now also introduced earlier in Finland. There is a general agreement that age should not be regarded as the only significant variable, but rather, as one of a number of variables to take into consideration. The Finnish national core curriculum for foreign languages states "there is plenty of room for joy, playfulness, and creativity in language learning" (POPS, 2014). However, the curriculum does not dictate what should be done in foreign language education, but rather how it should be done.

As play is important in the development of enthusiasm, motivation, and willingness to engage (Moyles, 2010) there is a great need to both use play in education as well as to get it right. If used successfully at the start of a child's foreign language teaching and learning play can help towards a general positive attitude for learning. A positive start to children's foreign language learning can create a strong foundation. (Macintyre, 2017).

Early foreign language teaching becoming a part of the national core curriculum makes early language learning goal oriented, and through that knowing language skills becomes assessable knowledge. In this article we have presented a Contextual-pedagogical early language learning landscape model planned for early foreign language teaching. This model will systematically develop both foreign language skills and transversal competence. The model is based on a theoretical framework of early foreign language learning, which takes into account the learner's era and the pedagogics of pre-primary and initial teaching as well as the learning environments.

The creation of this model has been carefully considered. In Finland teachers are highly educated and the research into teaching languages, as well as teaching methods are on a high level. Nevertheless, the way teachers choose to teach early foreing language may not necessarily be based on any particular language learning theory due to the fact that class teachers in Finnish schools are not trained to teach foreign languages in their teacher studies. With the help of the pedagogical model we will challenge both class and language teachers to teach early foreign language in such a way that makes it likely to be successful.

\section{References}

Celaya, M. (2012). "I wish I were three!": Learning EFL at an early age. In: M. GonzálezDavies \& A. Taronna (eds.), New Trends in Early Foreign Language Learning: The Age Factor, CLIL and Languages in Contact. Bridging Research and Good Practices. Cambridge: Cambridge Scholars' Publishing, pp. 2-12.

Common European Framework of Reference for Languages: Learning, Teaching, Assessment companion volume with new descriptors, 2018. Language Policy Programme Education Policy Division Education Department Council of Europe. https://rm.coe. int/cefr-companion-volume-with-new-descriptors-2018/1680787989 (retrieved 6.1.2019.)

Daryai-Hansen, P., Gregersen, A.S., \& Søgaard, K. (2014). "Tidligere sprogstart: begrundelser og praksisanbefalinger". Sprogforum, 58, 19-25. 
Euroopan Komissio (1995). Teaching and learning: Towards the learning society. Saatavilla: http://europa.eu/documents/comm/white_papers/pdf/ com 95_590_en.pdf (retrieved 11.1.2019.)

Graham, S., Courtney, L., Marinis, T. \& Tonkyn, A. (2017) Early Language Learning: The Impact of Teaching and Teacher Factors. Language Learning, 67(4), 922958.

Gilmore, A. (2011). I Prefer Not Text: Developing Japanese Learners' Communicative Competence with $\mathrm{Au}$ thentic Materials. Language Learning Journal - A na of Research in Language Studies, 61(3), 786-819.

Herrington, J., Reeves, T. C. \& Oliver, R. (2010). A Guide to authentic learning. New York and London: Routledge.

Jaekel, N., Schuring, M., Florian, M. \& Ritter, M. (2017). From Early Starters to Late Finishers? A Longitudinal Study of Early Foreign Language Learning in School. Language Learning, 67(3), 631-664.

Kangas, M. (2014). Leikillisyyttä peliin - Näkökulmia leikillisyyteen ja leikilliseen oppimiseen. In L. Krokfors, M. Kangas \& K. Kopisto (Eds.). Oppiminen pelissä. Pelit, pelillisyys ja leikillisyys opetuksessa. Tampere: Vastapaino Oy, 73-92.

Krashen, S. (1982). Principles and Practice in Second Language Acquisition. Oxford: Pergamon Press Inc.

Krashen, S. (1985). The input hypothesis: Issues and Implications. New Yors: Longman.

Keaveney, S. \& Lundberg, G. 2014. Early language learning and teaching: A1-A2. Lund: Studentlitteratur 2014.

Larson-Hall, J. (2008). Weighing the benefits of studying a foreign language at a younger starting age in a minimal input situation. Second Language Research, 24(1), 35-63.

Linna. S. (2018). Opettajien käsityksiä varhennetusta kielten opetuksesta. Fenomenografinen tutkimus täydennyskoulutuksen vaikuttavuudesta opettajien kokemana. Kasvatustieteen pro-gradu tutkielma. Luokanopettajien aikuiskoulutus. Kokkolan yliopistokeskus Chydenius. Jyväskylän yliopisto.

Littlewood, W. (1981). Communicative Language Teaching. An introduction. Cambridge: Cambridge University Press.

Macintyre, C. (2017). Enhancing Learning through Play: A developmental perspective for early years settings (3rd ed.). Oxon: Routledge.

Meriläinen, M. (2008). Monenlaiset oppijat englanninkielisessä kielikylpyopetuksessa. Rakennusaineita opetusjärjestelyjen tueksi. Department of Education, University of Jyväskylä. University Library of Jyväskylä.

Meriläinen, M. \& Piispanen, M. (2013b). Journey of exploration on the way towards authentic learning environments. Teoksessa: D. G. Sampson, J. M. Spector, D. Ifenthaler \& P. Isaias (toim.) Cognition and exploratory learning in the digital age. IADIS. 159-169.
Mezzi, T. (2012). Being Young, Being Adult: The Age Factor Issue for Vocabulary in Fl Education. Teoksessa M. Gonzales Davies \& A. Taronna (toim.) New Trends in Early Foreign Language Learning. Newcastle upon Tyne: Cambridge Scholars Publishing, 12-23.

Moyles, J. R. (2010). Thinking About Play: Developing a Reflective Approach. Maidenhead: McGraw-Hill Education.

Munoz, C. (2006). The Effects of Age on Foreign Language Learning: The BAF Project. Teoksessa C. Munoz (toim.) Age and the Rate of Foreign Language Learning. Second Language Acquisition 19. Clevedon, Buffalo, Toronto: Multilingual Matters LTD, 1-40.

Nissilä, L., Martin, M., Vaarala, H. \& Kuukka, I. (2006). Saako olla suomea? - opas suomi toisena kielenä -opetukseen. Opetushallitus.

Finnish National Board of Education (2004). National Core Curriculum for Basic Education 2004. Finnish National Board of Education.

Finnish National Board of Education (2014). National Core Curriculum for Basic Education 2014. Finnish National Board of Education.

Reinders, H. W. (2012). Towards a definition of intake in second language acquisition. Applied Research on English Language, 1(2), 15-36.

Rossi, J. (2013). Natural, unmodified, meaningful, motivating and real": Authentic Learning Materials and Authentic Learning Defined by FL Teachers and Teachers Students. Jyväskylän yliopisto. Kielten laitos. Pro gradu -tutkielma.

Rule, A. C. (2006). The components of authentic learning. Journal of Authentic Learning, 3(1), 1-10.

Salmela, R. (2011). Funktionaalisuus ja formaalisuus suomi toisena kielenä -opetuksessa. Opettajien ja opiskelijoiden haastattelukyselyn ja opiskelijoiden testitehtävän analyysi. Turun yliopisto. Kieli- ja käännöstieteiden laitos.

Swain, M. (1985). Communicative Competence: Some Roles of Comprehensible Input and Comprehensible Output in its Development. In S. Gass \& C. Madden (Eds.), Input in Second Language Acquisition. Rowley, MA.: Newbury House.

van Lier, L. (2004). The Ecology and Semiotics of Language Learning: A Sociocultural Perspective. Boston, MA: Kluwer Academic Publishers.

Villarroel, D. (2015). How young children learn English through play? https://www.britishcouncil.org/voices-magazine/how-young-children-learn-englishthrough-play (retrieved 29.12.2018.) 